\title{
Pentagon Fraud Analysis in Detecting Fraudulent Financial Reporting Using the Fraud Score Model
}

\author{
Roza Mulyadi ${ }^{*}$, Fita Rani Aulia², Mega Arum ${ }^{3}$ \\ University of Sultan Ageng Tirtayasa ${ }^{1^{*}}$, Banten College of Economics ${ }^{2,3}$ \\ Corresponding Author: roza.mulyadi@untirta.ac.id ${ }^{1 *}$
}

Keywords : Fraudulent Financial

Reporting, Fraud Pentagon

\begin{abstract}
This study was conducted to determine the effect of pentagon fraud (pressure, opportunity, rationalization, capability and arrogance) in detecting fraudulent financial reporting using F-Score in financial companies listed on the Indonesia Stock Exchange in 2017-2019. Using associative quantitative research methods. The population of this study are 100 companies with 49 sample of companies for 3 periods, so the sample total is 147 samples was obtained which was taken by purposive sampling technique. The testing method of this research is through multiple regression analysis with the SPSS 22 program. The results of the partial test analysis show that pressure and opportunity has significant effect in detecting fraudulent financial reporting. Whereas rationalization, capability and the arrogance variable has insignificant effect in detecting fraudulent financial reporting. The test results simultaneously are pressure, opportunity, rationalization, capability and arrogance has significant effect in detecting fraudulent financial reporting.
\end{abstract}




\section{Introduction}

The last process in the accounting cycle is the results obtained in the form of financial statements (Triastuti, et al., 2020). Financial statements present information about the financial position and performance of the company that helps users of financial statements in making decisions (Pribadi, et al., 2018).

Financial reporting standards must be relevant, not misleading to readers or those receiving information, easy to understand, reliable, and comparable (Abbas et al., 2020). Because if the company does not reflect its financial statements in real conditions, it will result in fraud (Fuad et al., 2020).

Financial statement fraud can be triggered because the agent feels he has the opportunity to commit fraud or pressure that demands the agent to carry out the company's operational activities properly from the principal (Abbas et al., 2020).

According to the Association of Certified Fraud Examiners (ACFE), fraudulent financial reporting is a deliberate misstatement of the reporting of the company's economic condition by misrepresenting or omitting financial information or disclosing financial information to obscure financial statement users in making decisions. (Akbar, 2017).

Agency theory is a contract that involves one or more people, in this case the principal employs another person (the agent) with the aim of providing a service and delegating authority to the agent in making the right and best decisions for the principal (Jensen, 2003). \& Meckling, 1976).

In essence, according to this theory, the relationship between shareholders or investors (principal) and management (agent) is difficult to create because of a conflict of interest (Agustina \& Pratomo, 2019). The agent has more information than the principal. This relationship can lead to a condition of information imbalance or often referred to as information asymmetry (Agustin, 2019). The conflict of interest and information asymmetry that occurs between the principal and the agent creates an attitude of distrust because the agent will act in the personal interest and not maximize the interests of the principal. This condition provides a great opportunity for agents to commit fraud (Agustina \& Pratomo, 2019).

Based on the results of a survey conducted by the ACFE Indonesia Chapter, it shows that the most detrimental fraud in Indonesia based on ACFE survey data (2020) is presented that corruption is in the percentage of $69.9 \%$, misuse of state and company assets/wealth at $20.9 \%$ and $9.2 \%$ for financial statement fraud. Despite being in the lowest rank, cases of financial statement fraud cannot be ignored because they will still cause bigger and bigger losses.

Accounting scandals to date have grown widely. One of the most well-known financial reporting fraudulent practices to this day is the ENRON case. The moral hazard behavior carried out by Enron itself was that the Enron company manipulated the profits listed in the financial statements of 600 million USD when in fact the Enron company suffered a loss. As a result of this fraudulent practice, Enron went bankrupt and left a sizeable debt of 31.2 billion USD (Zelin, 2018). 
One of the most popular cases and had become a discussion for accounting practices, especially banking accounting in Indonesia, was the case that occurred at Citibank which was carried out by a former Relationship Manager, Malinda Dee. Malinda Dee was charged with criminal acts of embezzlement of customer funds and money laundering of Rp 16.63 billion (Tessa \& Harto, 2016).

Another fraud case is the case of alleged window dressing 2018 financial statements by PT. Bank Tabungan Negara (BTN) in the form of lending that does not comply with the provisions to P.T. Asset Management Company (PPA). From this, it can be seen that the opportunity factor that motivates the directors of PT BTN is to minimize the company's bad loans by selling receivables. Then there is the ability factor which shows that there are efforts to improve the performance results of the previous directors that allow fraud to occur (Situngkir \& Triyanto, 2020).

Based on the company's fraudulent actions for various reasons, detection and supervision are needed. Detection of financial statement fraud is an initial effort to reduce asset misappropriation and earnings management abuse (Susilo et al., 2021).

In a survey conducted by the Association of Certified Fraud Examiner (ACFE) in 2019 it was shown that the financial and banking sectors were the sectors that experienced the most fraud cases compared to other sectors.

In this study, the researcher uses elements of Crowe's fraud pentagon theory as a basis for research in detecting fraud in financial statements because this theory is a refinement of Cressey's fraud triangle theory and Wolfe and Hermanson's fraud diamond.

From the description above, the authors are interested in conducting research with the title "Pentagon Fraud Analysis in Detecting Fraudulent Financial Reporting Using the Fraud Score Model"

\section{Research Method}

This research is quantitative and the method used in this research is descriptive and verification method. In this study, we will examine the causal relationship or influence of each variable consisting of independent variables, namely pressure proxied by financial targets, opportunity proxied by ineffective monitoring, rationalization proxied by change in auditors, capability proxied by change of director and arrogance proxied by dualism positions. And proxied on the dependent variable, namely financial statement fraud (F-Score) in financial sector companies listed on the Indonesia Stock Exchange for the 2017-2019 period.

The sampling method used is the purposive sampling method, namely sampling based on considerations and criteria. The sampling criteria in this study were financial sector companies listed on the Indonesia Stock Exchange (IDX) during the 2017-2019 period, presenting annual reports on the company website or IDX website for 3 years and experiencing no losses during the study period. Based on the predetermined criteria, there are 49 companies that meet the criteria 
for selecting the sample with an observation period of 3 years, so that the total observations are 147.

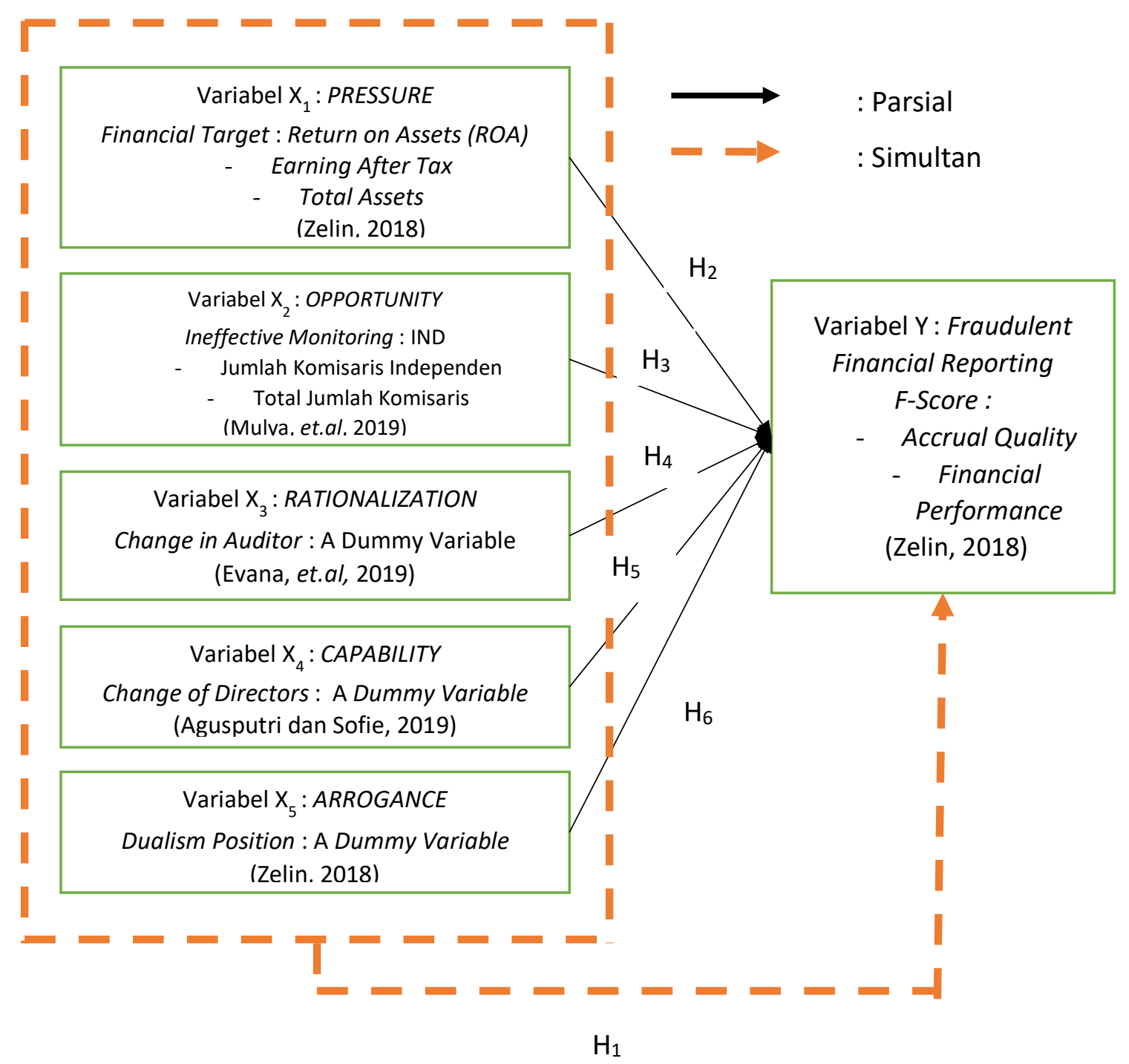

Figure 1. Conceptual framework 


\section{Result and Discussion}

Statistical Analysis Description

Panel A : Total Sample

Tabel 1. Descriptive Statistics

\begin{tabular}{lrrrrrr}
\hline & & & & & & \\
& $N$ & Minimum & Maximum & Sum & Mean & $\begin{array}{c}\text { Std. } \\
\text { Deviation }\end{array}$ \\
\hline ROA & 147 & .00 & .21 & 4.09 & .0278 & .02951 \\
IND & 147 & .25 & 1.00 & 77.45 & .5269 & .15125 \\
TAC & 147 & .01 & .99 & 51.63 & .3512 & .25125 \\
CDIR & 147 & 0 & 1 & 27 & .18 & .389 \\
DUALISM & 147 & 0 & 1 & 51 & .35 & .478 \\
FSCORE & 147 & .01 & 1.77 & 70.85 & .4820 & .33538 \\
Valid N (listwise) & 147 & & & & & \\
\end{tabular}

Panel B : Sub Sample Fraud

Table 2. Descriptive Statistics

\begin{tabular}{|c|c|c|c|c|c|c|}
\hline & $\mathrm{N}$ & Minimum & Maximum & Sum & Mean & $\begin{array}{c}\text { Std. } \\
\text { Deviation }\end{array}$ \\
\hline ROA & 12 & .01 & .21 & .91 & .0758 & .06273 \\
\hline IND & 12 & .33 & .67 & 6.27 & .5225 & .13692 \\
\hline TAC & 12 & .07 & .99 & 6.32 & .5267 & .28024 \\
\hline CDIR & 12 & 0 & 1 & 4 & .33 & .492 \\
\hline DUALISM & 12 & 0 & 1 & 6 & .50 & .522 \\
\hline FSCORE & 12 & 1.04 & 1.77 & 15.75 & 1.3125 & .24091 \\
\hline Valid N (listwise) & 12 & & & & & \\
\hline
\end{tabular}

Panel C : Sub Sample Non Fraud

Tabel 3.Descriptive Statistics

\begin{tabular}{lrrrrrr}
\hline & N & Minimum & Maximum & Sum & Mean & $\begin{array}{c}\text { Std. } \\
\text { Deviation }\end{array}$ \\
\hline ROA & 135 & .00 & .08 & 3.18 & .0236 & .02002 \\
IND & 135 & .25 & 1.00 & 71.18 & .5273 & .15292 \\
TAC & 135 & .01 & .95 & 45.31 & .3356 & .24358 \\
CDIR & 135 & 0 & 1 & 23 & .17 & .377 \\
DUALISM & 135 & 0 & 1 & 45 & .33 & .473 \\
FSCORE & 135 & .01 & .96 & 55.10 & .4081 & .22478 \\
Valid N (listwise) & 135 & & & & & \\
\hline
\end{tabular}


Table 4. Number of Companies Allegedly Detected in Fraud and Non-Fraud FRAUD

\begin{tabular}{cccccc} 
& & Frequency & Percent & $\begin{array}{c}\text { Valid } \\
\text { Percent }\end{array}$ & $\begin{array}{c}\text { Cummulative } \\
\text { Percent }\end{array}$ \\
\hline \multirow{3}{*}{ Valid $\quad$ Fraud } & 12 & 8,16 & 8,16 & 8,16 \\
& Non Fraud & 135 & 91,84 & 91,84 & 100,0 \\
& Total & 147 & 100,0 & 100,0 & \\
\hline
\end{tabular}

From the results of the F-Score calculation and descriptive analysis in the table above, it can be concluded that the number of sample companies indicated to commit fraud were 12 companies or $8.16 \%$, while for companies that were not detected as committing fraud, there were 135 companies or $91.84 \%$.

Normality test

Table 5. One-Sample Kolmogorov-Smirnov Test

\begin{tabular}{llr}
\hline & & $\begin{array}{r}\text { Unstandardiz } \\
\text { ed Residual }\end{array}$ \\
\hline $\mathrm{N}$ & Mean & 147 \\
Normal & Std. Deviation & .0000000 \\
Parameters & .30776550 \\
Most Extreme & Absolute & .064 \\
Differences & Positive & .064 \\
& Negative & -.038 \\
Test Statistic & & .064 \\
Asymp. Sig. (2-tailed) & $.200^{\text {c,d }}$ \\
\hline
\end{tabular}

Based on the results of the Kolmogorov-Smirnov test above, the Asymp value is generated. Sig. (2-tailed) of 0.200 . These results can be concluded that the residual data in this regression model is normally distributed because the value of Asymp.Sig. (2-tailed) above 0.05 and the regression model is suitable for further analysis. 
Multicollinearity Test

Table 6. Coefficients ${ }^{\mathrm{a}}$

\begin{tabular}{|c|c|c|c|c|c|c|c|c|}
\hline \multirow{2}{*}{\multicolumn{2}{|c|}{ Model }} & \multicolumn{4}{|c|}{$\begin{array}{c}\text { Standardize } \\
\mathrm{d} \\
\text { Coefficients }\end{array}$} & \multirow{2}{*}{ Sig. } & \multicolumn{2}{|c|}{$\begin{array}{c}\text { Collinearity } \\
\text { Statistics }\end{array}$} \\
\hline & & B & Std. Error & Beta & $\mathrm{t}$ & & Tolerance & VIF \\
\hline \multirow[t]{6}{*}{1} & (Constant) & .168 & .124 & & 1.356 & .177 & & \\
\hline & ROA & 4.303 & .975 & .379 & 4.413 & .000 & .812 & 1.232 \\
\hline & IND & .377 & .184 & .170 & 2.047 & .042 & .866 & 1.155 \\
\hline & TAC & -.114 & .116 & -.085 & -.980 & .329 & .786 & 1.272 \\
\hline & CDIR & .037 & .067 & .042 & .549 & .584 & .997 & 1.003 \\
\hline & DUALISM & .083 & .059 & .119 & 1.419 & .158 & .855 & 1.170 \\
\hline
\end{tabular}

a. Dependent Variable: FSCORE

From the research above, it can be concluded that all independent variables show a tolerance value $>0.10$ and a VIF value $<10$. Thus, it can be stated that the independent variables used in the regression model of this study are free from multicollinearity, reliable and objective.

Heteroscedasticity Test

Table 7. Coefficients ${ }^{\mathrm{a}}$

\begin{tabular}{|c|c|c|c|c|c|c|c|c|}
\hline \multirow{2}{*}{\multicolumn{2}{|c|}{ Model }} & \multicolumn{2}{|c|}{$\begin{array}{l}\text { Unstandardized } \\
\text { Coefficients }\end{array}$} & \multirow{2}{*}{$\begin{array}{c}\text { Standardize } \\
\mathrm{d} \\
\text { Coefficients } \\
\text { Beta }\end{array}$} & \multirow[b]{2}{*}{$\mathrm{t}$} & \multirow[b]{2}{*}{ Sig. } & \multicolumn{2}{|c|}{$\begin{array}{l}\text { Collinearity } \\
\text { Statistics } \\
\text { Toleranc }\end{array}$} \\
\hline & & B & Std. Error & & & & e & VIF \\
\hline 1 & $\begin{array}{l}\text { (Constant } \\
\text { ) }\end{array}$ & -5.127 & .890 & & -5.758 & .000 & & \\
\hline & ROA & 6.457 & 7.003 & .083 & .922 & .358 & .812 & 1.232 \\
\hline & IND & 1.056 & 1.323 & .070 & .799 & .426 & .866 & 1.155 \\
\hline & TAC & 1.577 & .836 & .173 & 1.887 & .061 & .786 & 1.272 \\
\hline & CDIR & .769 & .480 & .130 & 1.603 & .111 & .997 & 1.003 \\
\hline & DUALISM & -.334 & .422 & -.070 & -.793 & .429 & .855 & 1.170 \\
\hline
\end{tabular}

a. Dependent Variable: LNU2I

The results of the heteroscedasticity test above show that the significance value for all variables is more than 0.05 , so it can be concluded that there is no heteroscedasticity symptom in the regression model.

\section{Autocorrelation Test}

In this study using the Cochrane-Orcutt test and the Durbin-Watson detection (DW Test). The complete autocorrelation test results can be seen in the following table: 
Table 8. Model Summary

\begin{tabular}{lccccr}
\hline Model & $\mathrm{R}$ & R Square & $\begin{array}{c}\text { Adjusted R } \\
\text { Square }\end{array}$ & $\begin{array}{c}\text { Std. Error of } \\
\text { the Estimate }\end{array}$ & $\begin{array}{c}\text { Durbin- } \\
\text { Watson }\end{array}$ \\
1 & $.403^{\mathrm{a}}$ & .162 & .132 & .30087 & 1.994 \\
$\begin{array}{l}\text { a. Predictors: (Constant), Lag_XX, Lag_X4, Lag_X1, Lag_X2, Lag_X3 } \\
\text { b. Dependent Variable: Lag_Y }\end{array}$ & & \\
\hline
\end{tabular}

It can be concluded that $\mathrm{dU}<\mathrm{d}<4-\mathrm{dU}$ or $1.8012<1.994<2.1988$, so there is no autocorrelation in this test.

Model Feasibility Test (F Test)

Table 9. ANOVA ${ }^{\mathrm{a}}$

\begin{tabular}{|c|c|c|c|c|c|c|}
\hline \multirow{2}{*}{\multicolumn{2}{|c|}{ Model }} & \multirow[b]{2}{*}{ Sum of Squares } & \multicolumn{3}{|c|}{ Mean } & \multirow[b]{2}{*}{ Sig. } \\
\hline & & & Df & Square & $\mathrm{F}$ & \\
\hline \multirow[t]{2}{*}{1} & Regression & 2.593 & 5 & .519 & 5.287 & $.000^{b}$ \\
\hline & Residual & 13.829 & 141 & .098 & & \\
\hline & $\begin{array}{l}\text { Total } \\
\text { ependent Vari } \\
\text { redictors: (Con }\end{array}$ & $\begin{array}{l}16.422 \\
\text { le: FSCORE } \\
\text { tant), DUALISM, C }\end{array}$ & $\begin{array}{l}146 \\
R, T A C\end{array}$ & $\mathrm{ND}, \mathrm{ROA}$ & & \\
\hline
\end{tabular}

The table above shows the results of simultaneous testing between the variables pressure (X1), opportunity (X2), rationalization (X3), capability (X4) and arrogance (X5) against fraudulent financial statements $(Y)$. From the table, it is known that the significance value (Sig) is 0.000 . Because the significance value of $0.000<0.05$ is in accordance with the basis for decision making in the $\mathrm{F}$ test, it can be concluded that the variables pressure (X1), opportunity (X2), rationalization (X3), capability (X4) and arrogance (X5) simultaneously have a significant effect. to financial statement fraud $(Y)$ and the value of the regression fit.

Individual Parameter Test (t Test)

Table 10. Coefficients ${ }^{\mathrm{a}}$

\begin{tabular}{|c|c|c|c|c|c|}
\hline \multirow[b]{4}{*}{ Model } & & & \multirow{3}{*}{$\begin{array}{l}\text { Standardize } \\
\text { d } \\
\text { Coefficients }\end{array}$} & \multirow[b]{4}{*}{$\mathrm{t}$} & \multirow[b]{4}{*}{ Sig. } \\
\hline & \multirow{2}{*}{\multicolumn{2}{|c|}{$\begin{array}{l}\text { Unstandardized } \\
\text { Coefficients }\end{array}$}} & & & \\
\hline & & & & & \\
\hline & $\mathrm{B}$ & Std. Error & Beta & & \\
\hline $\begin{array}{ll}1 & \text { (Constant } \\
1\end{array}$ & .168 & .124 & & 1.356 & .177 \\
\hline ROA & 4.303 & .975 & .379 & 4.413 & .000 \\
\hline
\end{tabular}




\begin{tabular}{lrrrrr} 
IND & .377 & .184 & .170 & 2.047 & .042 \\
TAC & -.114 & .116 & -.085 & -.980 & .329 \\
CDIR & .037 & .067 & .042 & .549 & .584 \\
DUALISM & .083 & .059 & .119 & 1.419 & .158 \\
\hline
\end{tabular}

a. Dependent Variable: FSCORE

The pressure variable (X1) with the financial target proxy is known has a significance value (Sig) less than $0.05(0.00<0.05)$. The opportunity variable $(X 2)$ with ineffective monitoring proxy is known has a significance value $(\mathrm{Sig})$ less than $0.05(0.04<0.05)$. This shows that the pressure and opportunity variables has significant effect on fraudulent financial reporting, the hypotheses $(\mathrm{H} 2)$ and $(\mathrm{H} 3)$ are accepted.

The rationalization variable (X3) with the total accruals proxy is known has no significance value $(\mathrm{Sig})$ greater than $0.05(0.33>0.05)$. The capability variable $(X 4)$ with change of directors proxy is known has no significance value $(\mathrm{Sig})$ greater than $0.05(0.58>0.05)$. The arrogance variable (X5) with dualism position is known has no significance value ( $\mathrm{Sig}$ ) greater than 0.05 (0.16 $>0.05)$. This shows that the variables of rationalization, capability and arrogance has no significant effect on fraudulent financial reporting, hypotheses (H3), (H4) and (H5) are rejected.

Multiple Correlation Coefficient

Table 11. Model Summary ${ }^{b}$

\begin{tabular}{|c|c|c|c|c|c|c|c|c|c|}
\hline Model & $\mathrm{R}$ & $\begin{array}{c}\mathrm{R} \\
\text { Squar } \\
\mathrm{e}\end{array}$ & $\begin{array}{l}\text { Adjusted } \\
\text { R Square }\end{array}$ & $\begin{array}{l}\text { Std. Error } \\
\text { of the } \\
\text { Estimate }\end{array}$ & $\begin{array}{l}\text { R Square } \\
\text { Change }\end{array}$ & $\begin{array}{c}\text { Change } \\
\text { F } \\
\text { Change }\end{array}$ & Stati & $\begin{array}{l}\text { tics } \\
\mathrm{df2}\end{array}$ & $\begin{array}{l}\text { Sig. F } \\
\text { Change }\end{array}$ \\
\hline 1 & $.397^{a}$ & .158 & .128 & .31317 & .158 & 5.287 & 5 & 141 & .000 \\
\hline \multicolumn{10}{|c|}{$\begin{array}{l}\text { a. Predictors: (Constant), DUALISM, CDIR, TAC, IND, ROA } \\
\text { b. Dependent Variable: FSCORE }\end{array}$} \\
\hline
\end{tabular}

Based on table above, it is known that the value of sig. $\mathrm{F}$ Change is 0.000 less than 0.05 then there is a correlation between the independent variable and the dependent variable. Meanwhile, the value of the correlation coefficient $(R)$ is 0.397 , which means it shows a weak correlation.

Coefficient of Determination R2

Table 12. Model Summary ${ }^{b}$

\begin{tabular}{lcccr}
\hline Model & $\mathrm{R}$ & R Square & $\begin{array}{c}\text { Adjusted R } \\
\text { Square }\end{array}$ & $\begin{array}{l}\text { Std. Error of } \\
\text { the Estimate }\end{array}$ \\
\hline 1 & $.397^{\mathrm{a}}$ & .158 & .128 & .31317 \\
$\begin{array}{l}\text { a. Predictors: (Constant), DUALISM, CDIR, TAC, IND, ROA } \\
\text { b. Dependent Variable: FSCORE }\end{array}$ \\
\hline
\end{tabular}


From the table above, it can be seen that the Adjusted R2 value is 0.128 or $12.8 \%$. These results indicate that the dependent variable of fraudulent financial reporting as proxied by $\mathrm{F}$ score can be explained by the independent variables, namely the fraud pentagon proxied by financial targets, ineffective monitoring, total accruals, change of directors and dualism position of $12.8 \%$. Meanwhile, $87.2 \%$ was influenced or explained by other variables that were not included in this research model.

\section{Conclusion}

This study aims to empirically prove the effect of Pressure, Opportunity, Rationalization, Capability, and Arrogance on financial statement fraud in financial sector companies listed on the Indonesia Stock Exchange in 2017-2019, so the following conclusions can be drawn: the variables of pressure, opportunity, rationalization, capability and arrogance simultaneously has a significant effect on fraudulent financial reporting. Pressure variable has a significant effect on fraudulent financial reporting. The opportunity variable has a significant effect on fraudulent financial reporting. The rationalization variable has no significant effect on fraudulent financial reporting. The capability variable has no significant effect on fraudulent financial reporting. The arrogance variable has no significant effect on fraudulent financial reporting.

\section{Recommendation}

Based on the description of the discussion and the conclusions obtained, the following are suggestions that researchers can convey for further research: for further research, it is expected to use a wider research object so that it can generalize the research results to all companies listed on the IDX. It is hoped that further researchers can add proxy variables from the fraud pentagon such as financial stability, external pressure, the influence of industry nature, auditor turnover, number of CEO photos displayed, institutional stock ownership, external auditor quality, and capital turnover so that the scope of the research variables becomes wider.

\section{References}

Abbas, Di. S., Eksandy, A., Hakim, M. Z., \& Syam, I. (2020). Pengaruh Indikasi Kecurangan Terhadap Kecurangan Laporan Keuangan Dalam Perspektif Fraud Pentagon. Jurnal Ekonomi, Sosial \& Humaniora, 01(10), 55-64. https://jurnalintelektiva.com/index.php/jurnal/article/view/145

ACFE. (2020). Survei Fraud Indonesia. Association of Certified Fraud Examiners, 53(9), 1689-1699.

Adepurwanty, A., \& Rahman, A. N. (2019). Analisis Faktor-Faktor Yang Mempengaruhi Kecurangan Laporan Keuangan Dalam Perspektif Fraud Pentagon (Studi pada Perusahaan Sektor Infrastruktur, Utilitas dan Transportasi yang Terdaftar di Bursa Efek Indonesia Tahun 2016-2017). Journal Accounting and Finance, 3(2). 
Agusputri, H., \& Sofie, S. (2019). Faktor - Faktor Yang Berpengaruh Terhadap Fraudulent Financial Reporting Dengan Menggunakan Analisis Fraud Pentagon. Jurnal Informasi, Perpajakan, Akuntansi, Dan Keuangan Publik, 14(2), 105. https://doi.org/10.25105/jipak.v14i2.5049

Agustin, S. (2019). Pengaruh Fraud Pentagon Terhadap Kecurangan Pelaporan Keuangan di Indonesia pada Tahun 2018. Tidak Dipublikasikan.

Agustina, Ratna Dewi \& Pratomo, D. (2019). Pengaruh Fraud Pentagon dalam Mendeteksi Kecurangan Pelaporan Keuangan (Studi pada Perusahaan Sektor Pertambangan yang Terdaftar di Bursa Efek Indonesia Periode 2013-2017). Jurnal IImiah MEA (Manajemen, Ekonomi, \& Akuntansi), 3(1), 44-62.

Akbar, T. (2017). Using Pentagon Theory on Manufacturing Companies in. International Journal of Business, Economics and Law, 14(5), 106-113.

Amarakamini, N. P., \& Suryani, E. (2019). Pengaruh Fraud Pentagon Terhadap Fraudulent Financial Statement Pada Perusahaan Manufaktur Yang Terdaftar Di Bursa Efek Indonesia (Bei) Tahun 2016 Dan 2017. Jurnal Akuntansi, 7(2), 125-136.

Anggraini, Wiwit Rica \& Suryani, A. W. (2021). Fraudulent financial reporting through the lens of the fraud pentagon theory. Jurnal Akuntansi Aktual, 8(1), 1-12. http://journal2.um.ac.id/index.php/jaa

Aprilia. (2017). Analisis Pengaruh Fraud Pentagon terhadap Kecurangan Laporan Keuangan Menggunakan Beneish Model pada Perusahaan yang Menerapkan Asean Corporate Governance Scorecard. Jurnal Aset (Akuntansi Riset), 9(1), 101-132. http://ejournal.upi.edu/index.php/aset

Arens, A. A., Elder, R. J., \& B. M. S. (2015). Auditing dan Jasa Assurance Pendekatan Terintegrasi. Penerbit Erlangga.

Arikunto, S. (2014). Prosedur Penelitian Suatu Pendekatan Praktik. Jakarta : Rineka Cipta.

Crowe, H. L. (2010). IIA Practice Guide: Fraud and Internal Audit. Http://AibaUs.Org/Wpcontent/Iploads/2011/04/2010 0922AlBAFraud.Pdf.

Dwi Maryadi, A., Puspa Midiastuty, P., Suranta, E., \& Robiansyah, A. (2020). Pengaruh fraud pentagon dalam mendeteksi fraudulent financial reporting. Jurnal Akuntansi, Keuangan, Dan Manajemen, 2(1), 13-25. https://doi.org/10.35912/jakman.v2i1.104

Evana, E., Metalia, M., Mirfazli, E., Georgieva, D. V., \& Sastrodiharjo, I. (2019). Business Ethics in Providing Financial Statements: The Testing of Fraud Pentagon Theory on the Manufacturing Sector in Indonesia. Business Ethics and Leadership, 3(3), 68-77. https://doi.org/10.21272/bel.3(3).68-77.2019

Fuad, K., Lestari, A. B., \& Handayani, R. T. (2020). Fraud Pentagon as a Measurement Tool for Detecting Financial Statements Fraud. 115(Insyma), 85-88. https://doi.org/10.2991/aebmr.k.200127.017 
Ghozali, I. (2018). Aplikasi Analisis Multivariate dengan Program IBM SPSS 25. Badan Penerbit Universitas Diponegoro.

Jensen, M. C., \& Meckling, W. H. (1976). Theory of the Firm : Managerial behavior, Agency Costs and Ownership Structure. Journal of Financial Economics, 3(4), 305-306.

K, H. T., Rahayu, S., \& Riana, Z. (2020). Determinants of Fraud Pentagon Theory Perspective and Its Effects on Fraudulent Financial Statement in Mining Companies Which Is Listed In Indonesia Stock Exchange. Budapest International Research and Critics Institute-Journal (BIRCl-Journal), 3(3), 1995-2010.

Lestari, M. I., \& Henny, D. (2019). Pengaruh Fraud Pentagon Terhadap Fraudulent Financial Statements Pada Perusahaan Perbankan Yang Terdaftar Di Bursa Efek Indonesia Tahun 2015-2017. Jurnal Akuntansi Trisakti, 6(1), 141. https://doi.org/10.25105/jat.v6i1.5274

Maya Sandita Nasution, Elly Suryani, T. U. L. (2019). Pengaruh Fraud Pentagon terhadap Kecurangan Laporan Keuangan (Studi pada Perusahaan Manufaktur Sub Sektor Makanan dan Minuman yang Terdaftar di Bursa Efek Indonesia Periode 2013-2017). Jurnal AKSARA PUBLIC, 3(3), 153-165.

Mulya, A., Rahmatika, D. N., \& Kartikasari, M. D. (2019). Pengaruh Fraud Pentagon (Pressure, Opportunity, Rationalization, Competence dan Arrogance) Terhadap Pendeteksian Fraudulent Financial Statement Pada Perusahaan Property, Real Estate and Building Construction yang Terdaftar di Bursa Efek Indonesia. Permana: Jurnal Perpajakan, Manajemen, Dan Akuntansi, 11(1), 11-25. https://doi.org/10.24905/permana.v11i1.22

P. I., Santosa. (2018). Metode Penelitian Kuantitatif : Pengembangan Hipotesis dan Pengujiannya Menggunakan SmartPLS. Andi.

Pribadi, Suranta, \& M. (2018). Rasio-rasio keuangan dalam memprediksi kecurangan (10 (1)). Ilmu Akuntansi Ultima.

Purwanto, S., Hartini, S., Premananto, G. C., Astuti, S., Heriningsih, S., \& Veteran, U. (2019). Analysis Factor Triggers Fraud And Corporate Governance On Indications of Fraudulent Financial Reporting Using the Pentagon Fraud Theory Approach. Eksis, 14(1), 48-54.

Septriyani, Y., \& Handayani, D. (2018). Mendeteksi Kecurangan Laporan Keuangan dengan Analisis Fraud Pentagon. Jurnal Akuntansi, Keuangan Dan Bisnis, 11(1), 11-23. http://jurnal.pcr.ac.id

Siddiq, F. R., \& Suseno, A. E. (2019). Fraud Pentagon Theory Dalam Financial Statement Fraud Pada Perusahaan Terdaftar Di Jakarta Islamic Index (Jii) PERIODE 2014-2017 (Perspektif FScore Model). Jurnal Nusantara Aplikasi Manajemen Bisnis, 4(2), 128-138. https://doi.org/10.29407/nusamba.v4i2.13800

Situngkir, N. C., \& Triyanto, D. N. (2020). Detecting Fraudulent Financial Reporting Using Fraud Score Model and Fraud Pentagon Theory : Empirical Study of Companies Listed in the LQ 45 Index. The Indonesian Journal of Accounting Research, 23(03), 373-410. https://doi.org/10.33312/ijar.486 
Skousen, CJ, Smith, KR, \& Wright, C. (2008). Detecting and Prediciting Financial Statement Fraud: The Efectiveness od The Fraud Triangle and SAS nO. 99., 13.

Sugiyono. (2018). Metode Penelitian Pendidikan Pendekatan Kuantitatif, Kualitatif, dan R\&D. Alfabeta.

Sujianto, A. E. (2009). Aplikasi Statistik Dengan SPSS 16.0. Jakarta : Prestasi Pustaka.

Susilo, A., Masitoh, E., \& Suhendro, S. (2021). Fraud Pentagon in The Act of Cheating Financial Statements With The M-Score Method. Jambura Science of Management, 3(1), 36-45. https://doi.org/10.37479/jsm.v3i1.7142

Tessa C, H. P. (2016). Fraudulent Financial Reporting : Pengujian Teori Fraud Pentagon pada Sektor Keuangan \& Perbankan di indonesia. Simposium Nasional Akuntansi XIX, Lampung, $1-21$.

Triyanto, D. N. (2019). Fraudulence Financial Statements Analysis using Pentagon Fraud Approach. Journal of Accounting Auditing and Business, 2(2), 26. https://doi.org/10.24198/jaab.v2i2.22641

Zelin, C. (2018). Analisis Fraud Pentagon Dalam Mendeteksi Kecurangan Laporan Keuangan Dengan Menggunakan Fraud Score Model Halaman Sampul Skripsi Oleh : Nama : Cintia Zelin FAKULTAS EKONOMI UNIVERSITAS ISLAM INDONESIA YOGYAKARTA. 